\title{
JAMES FENIMORE COOPER AND THE IDEA OF ENVIRONMENTAL CONSERVATION IN THE LEATHERSTOCKING TALES (1823-1841)
}

\author{
Ceisy Nita Wuntu \\ IKIP Negeri Manado \\ c_wuntu@yahoo.com
}

\begin{abstract}
The spirit to respect the rights of all living environment in literature that was found in the 1970s in William Rueckert's works was considered as the emergence of the new criticism in literature, ecocriticism, which brought the efforts to trace the spirit in works of literature. Works arose after the 1840s written by Ralph Waldo Emerson, Henry David Thoreau, and Margareth Fuller, the American transcendentalists, are considered to be the first works presenting the respect for the living environment as claimed by Peter Barry. James Fenimore Cooper's reputation in American literary history appeared because of his role in leading American literature into its identity. Among his works, The Leatherstocking Tales mostly attracted European readers' attention when he successfully applied American issues. The major issue in the work is the spirit of the immigrants to dominate flora, fauna and human beings as was experienced by the indigenous people. Applying ecocriticism theory in doing the analysis, it has been found that Cooper's works particularly his The Leatherstocking Tales (1823-1841) present Cooper's great concern for the sustainable life. He shows that compassion, respect, wisdom, and justice are the essential aspects in preserving nature that meet the main concern of ecocriticism and hence the works that preceded the transcendentalists' work places themselves as the embryo of ecocriticism in America.
\end{abstract}

Keywords: Ecocriticism, James Fenimore Cooper, The Leatherstocking Tales, living environment, sustainable life

\section{Introduction}

The understanding of a literary work is usually related to the text, the writer, and the world (Glotfelty and Fromm, 1996, p. xix). Some materials on the environment are detected in The Leatherstocking Tales by James Fenimore Cooper, which are inseparable from the term 'the world' that precipitates the emergence of Cooper's attention to the environment. An in-depth analysis of the environment in a literary work is a part of the 'Ecocriticism.' Critics of the environment understand the world as an entire ecosphere that is broader in terms of scope than to understand the concept of the world which is commonly understood as social sphere (Glotfelty and Fromm, 1996, p. xix). It can be said that The Leatherstocking Tales appears from the impulse of the entire ecosphere. The spirit of exploitation to dominate the American plains that control every action was the spirit that was around Cooper when he was completing his work. Environmental Conservation ideas contained in these works were written in the early 19th century in a contemporary perspective regarding the current global environmental crisis, which underlines the role and ability of Cooper in raising the prestige of American literature, which is the focus of discussion in this work. 


\section{Methodology}

The examination on the ideas of environmental preservation in The Leatherstocking Tales follows the opinion of William Ruckert in Glotfelty and Fromn (1986) which signals the protection of nature. Referring to the first ecological law raised by Commoner, "man does not have the right to do anything he wants with nature. The idea that nature should also be protected...to articulate and defend their rights is one of the most marvelous and characteristic parts of the ecological vision" (p. 108). It guides reader in determining the direction of the focus of discussion in his work. The role of James Fenimore Cooper in The Leatherstocking Tales in maintaining safety and fighting for nature as the living environment can reveal his ideas on environmental conservation.

\section{Findings}

\section{Issues on Environmental Conservation 1. In The Deerslayer (1841)}

Natty Bumppo known as Deerslayer is the protagonist in this work. This work has another name which is "The First Warpath" because in this work Natty starts to be involved with the war at the age of 20. This work is important for two reasons, which are work contains ideas that are more mature and that this work describes the standpoint and the direction of Cooper. This maturity is also the base of his attitude of appreciation towards the environment and his role in realizing the belief of the importance of maintaining the harmony of the environment.

As the work is the first in The Leatherstocking Tales, it started with Natty Bumppo who is called a Deerslayer for appreciating the environment by showing a strong attitude towards the actions of the environment at such a young age. Natty's firm attitude expresses his steadfast confidence in the values of environmental conservation as well as his maturity. Confidence, assertiveness, and this maturity are growing strengths in the work of The Leatherstocking Tales. One example that shows maturity in this first work is when facing Hurry Harry, a friend he meets on her way to meet Chingachook and Uncas on a rock at the mouth of a river, while Hurry is heading towards Tom Hutter's residence. Hutter is older than Deerslayer but unmarried. In their conversation during the trip Hurry assumes that Deerslayer is much younger and therefore he considers more of Deerslayer as expressed in the phrase "Have you the gal's faith, to encourage you to hope otherwise?" Not at all, I know not how it is-I am good looking, boy..." (The Deerslayer, 1841, p. 506).

Hurry and Deerslayer's moral qualities in their statement look quite different compared with when Deerslayer understands that a good relationship should be based on the desire of the two parties, not just one-sided desire that will lead to coercion and not on the basis of love. Hurry does not value love, which must be owned by a couple who would later become husband and wife. Hurry does not heed the existence of love; he is relying on his power to dominate others, which has implications for the suffering of others and even the environment. He does not have appreciation for other people and the environment, so on that respect, wisdom and justice will never materialize in his life.

Environment inhabited by people like Hurry will suffer, or be damaged. Hurry in this work begins to be contrasted with Deerslayer when Hurry's interest in Judith Hutter begins to be interfered with by Deerslayer, Facing Hurry's attitude, although he feels younger, he always shows his stern face to Hurry who does not give any value to human life and does not add 
value to the existence of flora and fauna. In addressing the killings that occurred in the war, Hurry and Deerslayer have different views. Both are involved in the killing of man, in this case Mingos tribe, which is depicted to be always against the migrants who disturb them.

However, the cause of their involvement in the murder is different. Deerslayer does it due to the urgent situations when he has to suddenly protect himself from the barrage attack by the Indians. While Harry does it on purpose, together with Tom Hutter, Harry often disturbs the tranquility of Mingos tribe who feels that they have dignity in their fight when it is in war. Harry and Hutter both nurture a grudge against Mingos tribe by conducting reprisals against the Indians, although they are not attacked. They keep seeking the head of the Indians as a proof of their victory. The attitudes of underestimate and not giving value to humans with the desire to kill human beings are more apparent when Harry has the intention to kill any man who would become the husband of Judith Hutter. "If she has the courage to marry in my absence, she will ne like to know the pleasures of widowhood, afore she is twenty!" (The Deerslayer, 1841, p. 506).

Deerslayer has a different attitude with Hurry and Tom Hutter. His respect toward human lives is evident when he treats the killed Indians lovingly and not by cutting off their heads as Hurry and Hutter did. Deerslayer is against the beheading though it was done by the Indians who did the beheading to demonstrate their success in addressing the issues that are different from Hurry and Hutter who are doing it to satisfy the desire for revenge while they have Christian faith that teaches love. This opinion is analogized by Tom Hutter, "Treachery is an Indian virtue and the whites that live much in their tribes, soon catch Reviews their ways and practice"
(The Deerslayer, 1841, p. 550). Tom Hutter thinks that the scalping action undertaken by the Indians should be avenged in the same way, but ideally, according to the faith they believe in, such treatment does not have to be repaid with the same thing. It is written in the scriptures read by Hetty Hutter as a guide to life, "whosoever shall smite thee on the right cheek, turn to him the other also" (The Deerslayer, 1841, p. 672).

Other teachings believed by the whites that the murder and mistreatment done on purpose to our fellow human beings is also raised by Hetty, "Love your enemies, bless them that curse you, do good to them that hate you, and pray for them the which despitefully use you and persecute you" (The Deerslayer, 1841, p. 672). The ways of the civilized white people can be taught to the Indians who have a heart to appreciate the basic virtues, like when they show it to Deerslayer who abides by coming to give his life to the Mingoes after freeing Mingoes prisoners. Deerslayer, ignoring the fact that he is still 20, does not hesitate to refuse Harry's treatment and attitude. He says loudly to Hurry who intends to kill anyone who will win the heart of Judith Hutter as follows:

"If that man should be Judith Hutter's husband, after what has passed, I might tell enough, at least to put the Colony on trail...I would dare to speak truth, Hurry, concerning you, or any man that ever lived...You may shake Harry, until you bring down the mountain...but nothing beside truth will you shake from me. It is probable that Judith Hutter has no husband to slay, and you may never have a chance to way lay one, else would I tell her of your threat, in the first conversation I held with the gal..."(The Deerslayer, 1841, 507). 
The Deerslayer here also relies on the law as a way to overcome the attitudes that do not appreciate other fellow human beings. Deerslayer will not hide Hurry if one day there is a murder of the husband of Judith.

Natty in The Deerslayer had his first experience at war. Moral quality attached to it is based on the Christian belief that teaches people not to kill. The murders that happen in the woods are terrible incidents in his view and he thinks it would never be done by those who have the morals he has. His inner turmoil when facing a war is clearly visible:

"He was as yet unpractised in the ruthless expedients of savage warfare, of which he kne nothing except by tradition and theory, and it struck him as an unfair advantage to assail an unarmed foe. His colour has heighten, his eye frowned, his lips were compressed, and all his energies were collected and ready, but, instead of advancing to fire, he dropped his rifle to the usual position of a sportman in readiness to catch his aim, and muttered to himself, unconscious that he was speaking-"No-no-that may be redskin warfare, but it's not a Christian gift...we'll take it out like men; for the canoe he must not and shall not have. No-no; let him have time to load, and then God will take care of the right!"'(The Deerslayer, 1841, p. 594).

His religious belief does not allow him to kill. And for him, his enemies have to deal with him face to face and it is unfair to kill an enemy from behind. In desperation, such as in a state of war against him, murdering cannot be avoided when it threatens his life,

"I know'd it-I knowed it !" exclaimed Deerslayer, who was already preparing to force a fresh bullet into his rifle-"I know'd it must come to this as soon as I got the range from the creatur's eyes. A man sights suddenly, and fires quick, when his own life's in danger; yes, I know'd it would come to this. I was about the hundredth part of a second too quick for him, or it might have been bad for me! the riptyle's bullet has just grazed my side, but say what you will, for or ag'in 'em, a red-skin is by no means as sartain with powder and ball, as a white man. Their gifts don't seem to lie that-away. Even Chingachook, great as he is in other matters, is not downright deadly with the rifle."(The Deerslayer, 1841, p. 599).

In this quote, many times Deerslayer convinced him that killing in war is unavoidable when he is being threatened. Deerslayer is actually threatened when the bullets start to come towards him. In the quote: "I want none..." (The Deerslayer, 1841 , p. 507) it means that he does not want anything. It is the recognition that he did not pursue his personal interest to apply much less greed to destroy nature; human as well as flora and fauna. His mission is as he points out below:

"I look forward to a life in the woods, and I only hope it may be peaceable one. All young man must go on the war path when there's occasion, but war isn't needfully massacre... and I now invite you to go your own way, while I go mine ; and hope that we may part fri'nds" (The Deerslayer, 1841, p. 596).

It becomes clear here that despite his skin color, he would not side with the whites when white people are not on the path that he believes is right. Moreover, he presents a peace mission. He is forced to kill the Indians who are firing bullets towards him. His attitude towards the Indians who get killed shows that he regrets that it happened. He is 
totally against murder. This is evident from how he treats the helpless Indians:

"....and Deerslayer, after tossing the tomahawk into the canoe, advance to his victim, and stood over him, leaning on his rifle, in melancholy attention. It was the first instance in which he has seen a man fall in battle, it was the first fellow creature against whom he had ever seriously raised his own hand. The sensations were novel; and regret, with the freshness of our better feelings mingle with his triumph" (The Deerslayer, 1841, p. 599).

The habits that are often carried out by the Indians for scalping the deceased are later imitated as an act by white people who do not fully understand their own religious values but the Deerslayer does not participate. In contrary, he is extremely sad and has a feeling of uncertainty when looking at it.

Deerslayer is someone who does not justify the killing of men, except in cases when one is being threatened and in the care of his own safety and when there is an open fire. He hates the destruction of flora and fauna and admires the natural beauty unspoiled by civilization. $\mathrm{He}$ also has a role as a helper and protector such as when he has to protect the two girls, Judith and Hetty, and he explains that humans, flora and fauna are to be loved and appreciated. Deerslayer repeatedly refers to the teachings of Christianity. Hetty Hurry whose view of life is based on the holy books that Deerslayer also believes is shown by Cooper as a character that appears to emphasize Deerslayer's beliefs.

The protection given to Hetty Hurry, though she is an enemy, is only due to one reason that she is honest and true to what the Bible says. The criticism is made by the head of the Indian tribe towards Tom Hutter's father whom he regards as an enemy and who is a greedy Christian who is against the Indians, but who knows well the values in the Bible. So it can be said that the protection of the environment, in this case to humans, flora and fauna, can be maintained through the values of truth in Deerslayer's belief that is based on love.

The causes of damage on the environment are greed and extravagance that come from a heart that does not love others or the environment. The starting point of the ideal attitudes and behavior towards humans and the environment is owned by Deerslayer who is admired and loved by many people, both the Indians and the whites. Natty Bumppo's good attitude and behavior are based on his belief in Christianity that has a central teaching of love, to love other fellow human beings.

\section{In The Last of the Mohicans (1826)}

Frontier area in New York in 1757 is the background of this work. The background story is the war between France and England. In this war, the Indians are divided into two. The Indians that are easily bought are described here as Huron tribe, one of which is Magua or Le Renard Subtil. Natty Bumppo in this work is called Hawkeye or La Longue Carabine and he is an ally of the Delaware tribe. The tribe is known as a dignified tribe, and Hawkeye is raised in the midst of this tribe.

The environmental destruction in this work that makes it different from the other works in The Leatherstocking Tales is the destruction of one of the Indian tribes, the Mohicans, with the death of Uncas or Le Cerf Agile, the son of Chingachgook, also known as Le Gros Serpent. This tribe is a part of the good tribes of the Delaware. One element that was developed in this work relates to the conflicts 
between the Indians, between the French and the British, and between Indians and blacks. Another element is the views of Chingachgook who is left as the last of the Mohicans when the newcomers arrive, how they treat them as the first inhabitants in the new world and the depression as a result of the extinction of the tribe.

The conflict in this work is a struggle for power between France and England. The conflicts involving the Indians have caused bloodshed everywhere because there are mass killings that occurred. The extinction of the tribe of Mohicans in this work is an example of human greed that can lead to the destruction and the extinction of human beings. In this work, there is no presumption in favor of one of the races except their opposition to the prevailing evil or who ignore the interests of the environment. In a power struggle in this work, the victory is only expressed in the heart of Chingachgook, the last of the Mohicans, when facing the lamentations that are heard when his son was killed on the battlefield. Chingachgook felt that he had done noble work properly so he believes that he has dignity and honor.

There are three kinds of elements in the warring factions: the intruder, the intruded, or two warring parties that intrude on each other. The inner satisfaction of Chingachgook indicates that he and his group are troubled. The extinction of good people like the Mohicans is a symbol of destruction when the US just stays still while the Mohicans become extinct. Thus, the damaged environment in this work is spiritual and social environment. Thus, the idea of environmental conservation in this work is to overcome environmental destruction with the intent to do good without claiming someone else's belongings as practiced by the Mohicans.

\section{In The Pathfinder (1840)}

The Pathfinder is the third in the series based on the aging of Natty Bomppo. The background is Ontario Lake and the war between France and the Indians. The Indians who misbehave or have impressionable quality, paid to get out of the identity of their quality as dignified people also colors this story. Natty's identity as highlighted in The Deerslayer does not have any particular change in attitude and outlook toward nature and the environment. Similarly, the pattern of the plot is not that different from The Deerslayer, which involves assault, persecution, torturous violence, politeness, and romance.

The idea of environmental conservation in this work can be understood from Natty's love of the natural beauty of God's creation, longing for a respectful and courteous society which is aware of the different gifts given by God. The main idea developed in this story is about a sense of mutual respect and being prudent through the romance involving Mabel Dunham, Jasper Western, Pathfinder and David Muir.

Realistically, one woman later will only be owned by a man. Mabel Dunham is liked by those three men. Of the three men who want Mabel Dunham, there are three different ways to react. Jasper Western is addressing that he has the ability, honesty and courage as he demonstrated to the Pathfinder when he says that he wants Mabel Dunham.

On the other hand, David Muir is imposing his will. Faced with this problem, Pathfinder does not impose his will when he hears Jasper's confessions. Jasper Western is skilled in the race and really loves Mabel Dunham. Avoiding coercion is a way to avoid the destruction of the environment. Coercive attitude is to fulfill the desire to have whatever one wants, including flora and fauna with no 
thought of the reality, and by not having a heart that is willing to give. Therefore, collisions can occur which can lead to destruction.

\section{In The Pioneers (1823)}

This work is the first of the five works in "The Leatherstocking Tales" written by Cooper. The setting of place is in Cooperstown, around Otsego Lake in the frontier area by the Templeton that takes place from 1793-1794. In this series, Natty Bumppo is called Leatherstocking and he is seventy-one years old. This work contains adventure, morality, and the history of America. The main conflicts built in this work are the differences regarding the outlook and attitude towards life which occur between Natty Bumppo or Leatherstocking with the Templeton's vibrant rural communities that live from cutting trees, farming and animal husbandry.

Environmental destruction in this work is the cutting of trees which is done on pride, power and with the purpose of the collection of wealth as much as possible. Other environmental elements that were damaged are abundant birds in the air and plentiful fish in the lake which Templeton villagers harness as the source of their pleasure.

In this work, the Templeton villagers feel the benefit of the environment around them because they can get their food from the environment, such as fish, birds, and deer meat. Leatherstocking earns a living from the surrounding environment. A clear distinction between Templeton villagers and Leatherstocking is their way of life or their lifestyle. Regarding residence, Judge Temple owns a large building equipped with very luxurious household appliances, while Leatherstocking occupies only a very small hut in the forest. The cause of this difference can be understood from the phrase to Judge
Temple "Put an in, Judge, to your clearings ... Use, but do not waste" (The Pioneers, 1823, p. 250).

This expression does not mean that people cannot cut trees. It means that Leatherstocking is maintaining frugality and not destructive. Taking as needed is the way he wants to live. This expression, leads to the understanding that living in a hut is enough so that he can take shelter from the rain and heat. Building costs a lot and sacrifing a lot of natural resources. Understandably, Natty Bumppo is so upset with the attitude of Billy Kirby who wants to cut any trees on the hill just to show that he is the greatest and cannot be defeated. For fine dining in the celebration of feast days such as Christmas, Leatherstocking only requires a small bird, while Judge Temple and his colleagues need to kill five deer. Another commendable behavior performed in this work is the responsibility to rescue others that are weak. Leatherstocking has saved Elizabeth, the child of Judge Temple from tiger attacks and from the fire. His anger towards Judge Temple is not a reason to not help Elizabeth.

The essence of Leatherstocking's thinking about the environment is that the environment is the source of life. The idea that flora and fauna's lives should be maintained is seen when he argued Judge Temple about tree cutting and the destruction of the forests, stating "was not the woods made for the beast and birds to harbor in? And when men wanted for Reviews their flesh, Reviews their skin, or Reviews their feathers, there's the place to seek them" (The Pioneers, 1823, p. 250). A good way that must be applied to maintain the viability of the environment is to treat the environment with love, because only love can save a little bird that does not mean anything for the Templeton rural communities, like what Leatherstocking does when feeling 
affectionate towards a bird that was lying in agony (The Pioneers, 1823, p. 250).

Leatherstocking cannot bear to let the bird die as a result of shooting games done by Templeton villages. This occurs when there is empathy in Leatherstocking's heart, like when he compares the small birds to humans or to himself when he says that they only need their tongues to express their thoughts and feelings. In such circumstances, Leatherstocking was imagining himself being a wounded state, near death and as helplessness as the bird. Human strength cannot be combated by birds, therefore, to save the flora and fauna is a must as shown by the attitude of the Leatherstocking.

\section{In The Prairie (1827)}

The Prairie takes place in 1805 . This work tells the story of Natty Bumppo in old age at 82. Almost the same as The Deerslayer, this work also shows the maturity of Natty Bumppo, since the end of his life and the end of the story of The Leatherstocking Tales are in this work, so that this work reflects his maturity as parents. In this work, his nickname is the old trapper.

The development of the idea of environmental conservation in this work is built on moral actions by Natty Bumppo or old trapper as he did in other works in "The Leatherstocking Tales", such as the actions of giving help and liberation. Old trapper in this work helps the family of Ishmael Bush in the Great Plain after the Louisiana Purchase in 1803. As usual, he gives help and protection. He also gives assistance and protection to Middleton by helping free his wife Inez who was kidnapped by Abiram White, Esther's brother, the wife of Ishmael Bush.

Then, the idea emerged from a clash between the good and bad, between the treatment of migrants and the old trapper to the environment. In a controversy, old trapper is always on the side of what is good and commendable. In this work, the old trapper, again, admires the nature of courage displayed by a young Pawnee fighter from the tribe named Hard-Heard. Nevertheless, the old trapper did not accept the desire to end other people's lives when he said: "Pawnee, I love you; but being a Christian man, I cannot be the runner to bear such a message" (The Prairie, 1823, p. 819). The desire to kill people according to old trapper should not be maintained. This feeling is a superior feeling granted when a man can be killed freely and it is beginning of cruelty towards flora and fauna.

Compassion for one another and for the environment needs to be maintained to keep the harmony of the environment. References to scripture believed by Natty are rediscovered in this work. Protection of the environment in this work is in the form of respect for the law made by man to protect the environment. West area, which is free from migrants is considered a place to commit crimes freely since they see that the manmade law cannot reach them in the wild.

Natty does not accept it even though he prefers to always move around the free areas. His trip to the free region is the rejection of the attitudes and behaviors of malicious newcomers to the environment. The strength of the idea of environmental conservation in this work is that the environment should be maintained with the laws of man. The old trapper's hatred is shown by refusing to stay together with the settlers in the colonysettlement which indicates the absence of tolerance towards anyone who damages the environment.

Damaging the environment is not necessary because according to the old trapper, nature 
has provided for the needs of man. The food available in nature is already tasty, so there is no need to add seasoning made by man. A solid defense for the environment of the old trapper is when he decides to stay together with good Pawnee tribe in the barren Great Plain area than with those white people who damage the environment when they justify the killing of human beings. The destruction of flora and fauna will be easier to do by them than by man who has the ability to resist. Old trapper is not able to justify the killing when he practices his religious belief properly when he warned the young Pawnee fighter he admired that the teachings which he believed did not justify murder.

In Christianity, the Bible is the religious reference. It is written in it that "Thus live these three things: faith, hope and love, and the greatest of them is love" (1 Corinthians 13:13). In another part of the Holy book it is written, "and the second law is: Love thy neighbor as yourself" (Matthew 22:39). The old trapper's attitude towards humanity is greatly influenced by Christianity. Loving others will prevent people from doing as they please.

The Leatherstocking Tales as embryos of Eco-criticism in America

The Leatherstocking Tales contains the spirit of exploitation in connection with the eviction of the Indian Cherokees executed in 1838. The extinction of the Mohican tribe and the attitude and behavior shown by the newcomers towards the flora and fauna show the lack of their understanding that nature can affect human. Nature is an important element which should be considered by humans as exemplified by the writers of American literature. Henry David Thoreau's opinion in "Walden" is that nature "is hard to be overcome but she must be overcome" (Thoreau, 1971, p. xvi).
This opinion is also justified by Cooper, Nathaniel Hawthorne and Herman Melville. The third author believes that nature can affect and influence people. Natty Bumppo concerns against forest destruction which will result in animals losing their habitat which can also lead to human catastrophe. Violations of norms by Hester Bryne and Pastor Dimmesdale are also due to the restraint of the natural properties inherent in both of individuals that can result in death as experienced by Dimmesdale. The same thing happens to Captain Ahab who tries to fight a giant whale in Moby Dick. The size of the whale will not be able to be defeated by Captain Ahab, though he is well known as an expert in killing whales. The fight finally takes his life. Addressing the existing problems in each of these works, Cooper chooses to react in a manner that is not greedy and frugal, Hawthorne deals with attention and love, and Melville responds not with dexterity but with ingenuity.

Humans also have balanced power of nature according to Thoreau. In his work Walden, he says that humans naturally possess wildness and goodness. They like both of them (Thoreau, 1971, p. 210). Thoreau's definition of balance also appears in The Leatherstocking Tales. In some of the issues, Cooper is always in the 'middle position'. Wilderness is a symbol of freedom, but Natty Bumppo's desire to follow the forest that he loves due to the environmental destruction that he does not like is not a decision to acquire absolute freedom as freedom inhuman laws. Abiram's desire in The Prairie to stay in the wild as 'prairie' is a motivation to find freedom from the human laws. In the end, he committed a murder to assume that the 'prairie' is a free area from the law.

Thus, Cooper is not on a particular side when confronted with the conflicts between whites 
with whites, Indians with Indians, Indians with whites, and vice versa. Cooper does not choose Judith whom he admires as his wife even though she was a bright girl, he does not choose Hetty either, his sister, who obeys the teachings of religion, in his work The Deerslayer. Cooper does not choose the old Ta Wah Wah who becomes his lover in The Pathfinder, nor the young Judith. 'The middle position selected by Cooper is a strong understanding of the nature and its properties.

From writers who wrote about the significance of the nature above, Cooper is the author of nature that accommodates the physical, social and spiritual environment. Hawthorne's defense is on the properties that stick to human beings when Hester Prynne was so strong in character as well as his defense of nature, which he has in himself as he prefers to be punished in prison and scaffold or by hanging and humiliated in the market place. Natural elements that Hawthorne raised are different with natural elements raised by Cooper. Hawthorne chooses natural properties of the human psyche or mentality. Hester Prynne and Dimmesdale feel different when Hester Prynne violates the rule because she was neglected by her husband Chillingworth, while Arthur Dimmesdale feels that he commits treason against the trust of parishioners.

Hawthorne here distinguishes the quality of the offense. Vices of human nature are ultimately defeated when Dimmesdale dies because of the pressure of guilt against the prevailing norms in the society. Dimmesdale's death is a result of psychological pressure to neglect the rules of society.

“...Happy are you, Hester, that wear the scarlet letter openly upon your bossom! Mine burns in secret...now it is all falsehood!-all emptiness!-all dead!”...O
Hester Prynne, thou little, little knowest all the horror of this thing! And the shame-the indelicacy!-the horrible ugliness of this exposure of a sick and guilty heart to the very eye that would gloat over it!” (Baymn, 1989, p.1265).

Some secret mistakes have made Dimmesdale suffer and eventually die. The mode of nature, which is reflected here is that every human being has natural properties that are unscrupulous to demonstrate their capacity as a savior. Hester's obstinacy is Hawthorne's recognition to the needs of attention for the human soul. Hester believes that what he did would be justified by God (Baymn, 1989, p. 1265).

Dimmesdale's death is Hawthorne's attitude that does not tolerate an attitude which is against natural moral stance contained in man. Hawthorne has the same attitude toward nature, that nature cannot be resisted. Both authors differ in the scope of nature's size that they manage, although in principle they reject the bad traits of nature. Both have an ecocentric attitude. Dimmesdale's moral attitude, even though he eventually dies, is Hawthorne's form of defense against moral values, as well as the moral values that are believed by Hester Prynne, which are protected by Hawthorne with the opportunity to continue living. Cooper is also eco-centric. Natty Bumppo's hut in the forest and the extinction of the Mohican tribe indicate the dialectic between cause and effect.

The extinction of the Mohican tribe causes Natty Bumppo to restrain his natural human desire on the abundance of properties that is shown by the migrants who exploit the environment. Melville also has an eco-centric moral soul when human's revenge eventually is defeated by the nature. It is the same with Cooper, Hawthorne and Melville, who show eco-centric moral attitude, with different 
displayed nature. Cooper, Hawthorne and Melville show the similarity of view about the positive and negative of nature. Melville has a strategy to play with nature that cannot be changed by man with moral values and wisdom and not with the attitude shown Captain Ahab (Melville as cited in Baymn et al, 1989, pp. 2157-2158).

The spirit, which is owned by Captain Ahab is the spirit of arrogance that consider as he considers himself great, powerful and more than others. With the spirit of arrogance, by relying on his physical abilities, he advances to conquer the giant whale but eventually dies. Thoreau does not dismiss nature in human beings. In "Higher Laws" in Thoreau's "Walden", he says, "I love the wild not less than the good" (Thoreau, 1971, p. 210).

However, Thoreau's recognition gives a sense of tolerance or gives place to the bad natural properties which are circumvented by Cooper, Hawthorne and Melville. Whitman also appreciates nature but he prefers to be anthropocentric. For him, nature can be used for the benefit of man. Although Whitman has a noble purpose to meet his Lord in the journey to the east like in "Passage to India," he has a dominant admiration to technological developments for the sake of the people. The eco-centric attitude of Cooper in The Leatherstocking Tales has a broader level, as Cooper describes the physical elements of nature such as flora, fauna and humans in a unity that are justified by ecological principles. Cooper has a tight defense against living natural elements.

Thus, it can be said that the ideals of Walt Whitman at the time were being fought by the migrants, which makes America as a modern country, advanced in technology, although in a way damaging the environment, such as the extinction of Mohican tribe, as well as the cutting of trees for amassing wealth as was done by Billy Kirby in The Pioneers and the fauna mass murder in the village of Templeton for pleasure.

Materials about environmental safety in the work of Cooper The Leatherstocking Tales began to be written two years after he wrote his first novel The Precaution (1821). Through his work, fighting for a good cause towards the environment that he began in 1823, forty-seven years after American independence, Cooper already reminded the country to be sensible to the natural environment and human environment around it. Cooper's popularity in the 19th and 20th centuries exceeded writers like Thoreau, Melville, and Whitman. These three authors were discovered by modern readers when they got American awards. Cooper's fame in obtaining national literature from the quality of his works reveals the identity of American literature, which is "American-ness" as the emergence of varied dialects, 'frontier' background area and familiar characters that are often heard in the area, and the theme of the ideas of a new republic (Walker, 1962, p. 120).

Cooper is regarded as "the first American writer to express a sense of concern for the wanton destruction of the environment." Cooper's love for the natural world began when he was always close to nature, and familiarity with the nature made him miss it, so he did not like the activities of eviction of forest, flora and fauna undertaken by migrants (Franklin, 2007, p. 12). The benefits provided by the universe are actually traceable in his memory. His attention to the flora and fauna was born for the longing to the quiet time in the beautiful American wilderness that was once his playground. Untouched American nature in his childhood has been cultivating his love of flora and fauna so that changes that occurred when flora and fauna started to be evicted led to hatred against the frontiersmen. 
The cacophony of the activities of the frontiersman had been disturbing the peace of flora and fauna, which he had acquired in the wilds of America. "Cooper was indeed making a social and moral issue out his own sense of loss. The loss was visual, as his emphasis on the ugliness of the frontiers the stump-strewn landscape suggest" (Franklin, 2007, pp. 12-13).Cooper's knowledge on how to treat the natural and human environment was a value that was very expensive to have in this new nation which was officially formed on July $4^{\text {th }}, 1776$. This is in accordance with the principles of ecology that emphasizes the absolute dependence of each other between all the elements that exist on the earth (Odum, 1971, pp. 1-3).

The dream of the settlers that a new world is a place that promises a better life has resulted in the exploitation of the environment such as; the cutting of trees to be used to build settlements as well as a commodity to be marketed to countries in Europe and the killing of animals for the use of their leather and fur which will be sold in Europe as well as for fun for the newcomers are the environmental issues portrayed by James Fenimore Cooper. When such exploitation makes the quality of the environment unstable, and when it is not addressed, it will maintain an un-commendable attitude of the newcomers towards the environment. Since very early, Cooper had dreams to straighten the migrants to 'life, liberty and the pursuit of happiness' which contains values of environmental sustainability.

The success of Cooper's observation of the urgency of his country's future was projected from the state of super abundance accompanied by a strong self-belief that superior European settlers were a consequence of a superior quality. That quality is reflected in the nature of Cooper's persistence in facing many challenges as a writer in the era of early America, the challenges in his personal life, his concern for the condition of American literature, the intention with the spirit of patriotism and concern for the environment, the flora, fauna and humans in America even around the world in general.

As the first American writer who cares about the environmental damage and presenting the ideas of environmental preservation in The Leatherstocking Tales (1823-1841), he became viable as an environmentalist in America when this work was recognized as a monumental work. It was necessary to warn the Americans, even all of humankind to the dangers of environmental destruction. Historically, eco-criticism in America refers to works that glorify 'nature' from the 'transcendentalists' in 1840 s which are the works of Ralph Waldo Emerson (1803-1882), Henry David Thoreau (1817-1862), as well as Margaret Fuller (1810 -1850), while in the UK in the works of William Wordsworth in the English Romantic period in the 1790s (Barry, 2002, p. 250).

Eco-criticism applies a 'natural science' concept which is different from the domination of other criticisms that do not accommodate these fields in analyzing literature (Dodd, 2014).Cooper's intelligence in the work is not limited to providing admiration for the natural beauty but more in the issues that arise in the present period as hatred against pollution (The Prairie, 1827, p. 674), as well as the concept of alive habitat, when he is worrying about the life of the fauna habitat being destroyed in the forest (The Pioneers, 1823, p. 250). This thinking has emerged in the period prior to the 'Transcendentalist.' This factor qualifies the work of Cooper The Leatherstocking Tales is an embryo of eco-criticism. The other reason is that, historically, the work appears before 
the works of the 'Transcendentalists' which appears after 1840 , earlier than the effort to save the environment in the United States pioneered by John Muir, Theodore Roosevelt and Pinchot in the 1850s and emerged much earlier from the birth of the environmental legislation in the United States in September 1964.

\section{Conclusion}

Cooper's integrity in American literature has been determined by the integrity to the natural environment, the state and nation, humanity and to life. The relevance of the ideas of environmental preservation in Cooper's work The Leatherstocking Tales with current environmental issues has placed the work as a monumental work in the world, from the properties or nature of the world raised by Cooper, which can never be changed by time and is universal. Therefore, eco-criticism that emerges in the era of post-modernism can still refer to the work of Cooper. Thoreau, Emerson and Margaret Fuller mentioned as forerunners of eco-criticism in America have actually been preceded by Cooper, and Cooper also preceded other American writers who wrote about nature like Hawthorne, Melville, and Whitman. These factors can meant that the works of James Fennimore Cooper's The Leatherstocking Tales as an embryo of eco-criticism and can put Cooper in the category of environmentalists in America, together with Thoreau, Muir, Roosevelt and Pinchot.

\section{References}

Barry, P. (2002). Beginning theory: An Introduction to Literary and Cultural Theory. Manchester university Press. UK.

Baym, N., et al. (Eds). (1989). The Norton Anthology of American Literature (3rd ed., Vol. 1.). W.W. Norton \& Company. New York. . (2003). Cherokee Memorials. In The Norton Anthology of American Literature. (6th ed. Vol. B). W.W. Norton \& Company. New York. 10291039.

Cooper, J. F. (1985). The Leatherstocking Tales; Volume I (The Pioneer, The Last of The Mohicans, The Prairie). The Library of America. USA. . (1985). The Leatherstocking Tales; Volume II (The Deerslayer, The Pathfinder). The Library of America. USA.

Cooper, J. F. (1979). Introduction: The Last of The Mohicans. Dodd, Mead \& Company. New York.

Dodd, E. (21 October 2014). Ecocriticism: Literary Studies in an Age of Environmental Crisis. Natural Resources and Environmental Sciences Seminar Series. Kansas State University, Ackert 231.

Franklin, W. (2007). James Fennimore Cooper: The Early Years. Yale University Press. USA.

Glotfelty, C. and Fromm, H. (Eds). (1996). The Ecocriticism Reader Landmarks in Literary Ecology. University of Georgia Press. Georgia.

Lauter, P. (2009). The Arrival of The Whites. In The Heath of Anthology of American Literature (6th ed. Vol. A). Wadsworth. New York. pp. 74-79.

Lembaga Alkitab Indonesia, Alkitab, Jakarta.

Lounsbery, T. (1886). James Fennimore Cooper. Houghton, Mifllin and Company. New York.

Mc Michael, G, et al (Eds). (1980). Anthology Of American Literature, (2nd ed., Vol. 1). Macmillan Publishing Co. Inc. New York.

Muir, J. (1985). The American Conservation Movement. The University of Wisconsin Press. Wisconsin. 
Odum, E. P. (1971). Fundamentals of Ecology. W. B. Saunders Company. USA.

Shanley, J. L. (ed.). (1971). Walden. Princeton University Press. New Jersey.

Smith, C. J. (1624). The General History of Virginia. The Fourth Book. Wisconsin Historical Society. Wisconsin.

Spiller, R. E., Throp, W., Johnson, T.H., Canby, H.S, Ludwig, R.M., Gibson , W.M. (Eds). (1974). Literary History of The United State. McMillan Publishing Co., Inc. New York.
Spiller, R. E. (1965). James Fennimore Cooper. McGraw-Hill Book Company. New York.

Walker, W. S. (1862). James Fennimore Cooper: An Introduction and Interpretation. Barnes \& Noble, Inc. New York.

Whitman, W. (1900). A Passage To India. Retrieved from http://www.bartleby.com/142/183.htm 1. 
